\title{
ФОРМУВАННЯ НАВИЧОК ЕФЕКТИВНОГО СПІЛКУВАННЯ ПЕРШОКЛАСНИКІВ ЗАСОБАМИ ДИДАКТИЧНОЇ ГРИ В УМОВАХ НОВОЇ УКРАЇНСЬКОЇ ШКОЛИ
}

\author{
Алексєєва О. Р., Курліщук I. I.
}

\section{ВСТУП}

Інтеграція України у світовий освітній простір, підвищення якості освіти 3 урахуванням інтересів та психологічних особливостей сучасних дітей зумовили необхідність модернізації системи освіти, оскільки традиційна парадигма «знання $\rightarrow$ вміння $\rightarrow$ навички» вже неефективна для формування особистості, здатної до вільного орієнтування в різних сферах полікультурного простору.

Нова концептуально й організаційно школа почалася в Україні 1 вересня 2018 року реформуванням 3 початкової ланки й спрямована на компетентнісну освіту, яка має ефективно підготувати особистість до самореалізації в суспільстві, прищепити прагнення до самовдосконалення й навчання впродовж життя, що забезпечується шляхом формування ключових компетентностей. Такими в Новій українській школі (далі - НУШ) є вільне володіння державною мовою, здатність спілкуватися рідною (у разі відмінності від державної) та іноземними; математична, інформаційно-комунікаційна, екологічна компетентність, компетентності в галузі природничих наук, техніки й технологій, інноваційність, навчання впродовж життя, громадянські та соціальні компетентності, культурна компетентність, підприємливість та фінансова грамотність. Спільними для всіх вищеназваних $є$ вміння читати й розуміти прочитане; уміння висловлювати думку усно й письмово; критичне мислення; здатність логічно обгрунтовувати позицію, виявляти ініціативу, оцінювати ризики й приймати рішення; уміння конструктивно керувати емоціями; здатність співпрацювати в команді ${ }^{1}$. Тому актуальною в сучасній школі постає проблема формування комунікативної компетентності учнів, що диктується вимогами життя й стає об'єктом вивчення в даній роботі.

Комунікативна компетентність тісно пов'язана зі спілкуванням i комунікацією та вивчається різними науковими галузями. Учені-дидакти,

Концепція Нової української школи / упорядники Гриневич Л., Калашнікова С., Коберник I., Ковтунець В., Шиян Р. та ін. заг. ред. М. Грищенко. Київ, 2016. URL://https://mon.gov.ua/ua/ osvita/.../nova-ukrayinska-shkola 
методисти, психологи, лінгвісти (А. Андреєв, Н. Бібік, В. Бондар, Л. Божович, М. Вашуленко, І. Гудзик, О. Леонтьєв, В. Мельничайко, М. Пентилюк, О. Прищепа, О. Савченко тощо) розглядають комунікативну компетентність не лише як мету навчальної діяльності, а як одну із важливих умов формування успішності молодшого школяра в освітньому процесі.

Для формування навичок ефективного спілкування першокласників необхідним $\epsilon$ виявлення та обгрунтування відповідних психологопедагогічних передумов, однією 3 яких має стати широке доцільне використання дидактичних ігор як ефективного засобу формування комунікативної компетентності першокласників, що найбільше відповідає психологічним особливостям сучасної дитини молодшого шкільного віку й найбільш актуальне для реалізації завдань сучасних Державних освітніх стандартів на основі застосування нових педагогічних технологій у системно-діяльнісному підході до навчання.

Ефективність дидактичних ігор у навчанні молодших школярів переконливо доведено в роботах Ш. Амонашвілі, Н. Бібік, М. Вашуленка, Б. Друзя, Ю. Калинецької, С. Короткова, Н. Кудикіної, М. Микитинської, Р. Осадчук, Н. Підгорної, О. Савченко, Г. Цукерман, Т. Шмакової тощо.

Попри багатоаспектне вивчення окремих аспектів проблеми, дидактична гра як засіб формування навичок ефективного спілкування учнів 1-го класу НУШ із застосуванням новітніх освітніх технологій, які найбільш відповідають психолого-педагогічним особливостям сучасних дітей, а отже, найкраще сприяють реалізації освітніх завдань - формуванню життєздатної, соціально активної та успішної особистості, натепер вивчено недостатньо, що й визначає актуальність даної наукової розвідки.

\section{1. Комунікативна компетентність}

\section{як умова ефективного спілкування}

Уміння ефективно спілкуватися - один із чинників успіху в будьякій сфері сучасного життя. Знання сутності, закономірностей, функцій спілкування $\epsilon$ підгрунтям для встановлення сприятливих стосунків 3 іншими людьми й задоволення потреб особистості в самореалізації. Саме цю думку підтверджують висновки С. Рубінштейна про важливість спілкування як «необхідної передумови будь-якої діяльності людини» ${ }^{2}$ в становленні ії особистості.

${ }^{2}$ Рубинштейн С.Л. Проблемы общей психологии / ред. Е.В. Шорохова. Москва: Педагогика, 1979.416 с. 
Ефективність спілкування визначається рівнем комунікативної компетентності особистості, який відкриває перед людиною нові можливості: правильне й точне висловлення власної думки стає запорукою порозуміння з іншими людьми й самореалізації.

Учені різних галузей, як зазначалося у вступі до роботи, одностайні в тому, що комунікація є основним способом існування особистості, головною умовою іï навчання й виховання, розвитку й формування громадянина в сучасній соціокультурі, тому комунікативна компетентність набуває особливої значущості в наш час, що диктується вимогами життя i визначається як ключова компетентність учнів початкової школи.

Щоб з'ясувати сутність поняття «ефективне спілкування першокласників», зупинимося на короткому аналізі основних його складників.

Отже, «спілкування». 3 психологічного, педагогічного та лінгвістичного аспектів. Найавторитетніші словники дають такі трактування: спілкування - узаємні стосунки, діловий, дружній зв'язок³ дія за значенням спілкуватися: по-перше, підтримувати взаємні стосунки, діловий, дружній зв'язок із ким-небудь, розуміти одне одного; порозуміватися; по-друге, об'єднуватися для спільних дій ${ }^{4}$.

Поняття спілкування у психологічній літературі вживається в різних значеннях: як обмін думками, почуттями, переживаннями (Л. Виготський, С. Рубінштейн); як один із різновидів людської діяльності (Б. Ананьєв, М. Коган, І. Кон, О. Леонтьєв); як специфічна соціальна форма інформаційного зв'язку (О. Урсун, Л. Рєзніков); як взаємодія, стосунки між суб'єктами, які мають діалогічний характер (Г. Андрєєва, В. Соковін, К. Платонов).

Л. Виготський зазначає, що вищі, властиві людині форми психологічного спілкування можливі тільки завдяки тому, що людина за допомогою мислення узагальнено відображає дійсність 5 .

Отже, спілкування - це обов'язкова умова формування загального інтелекту, мислення, пам'яті, сприймання, уваги; це процес встановлення і розвитку контактів між людьми, який породжується потребами спільної діяльності і містить обмін інформацією, розширює

${ }^{3}$ Словник української мови: в 11 т. / АН УРСР. Інститут мовознавства; за ред. I. К. Білодіда. Київ: Наукова думка, 1970-1980. Т.9. С. 254 URL: http://ukrlit.org/slovnyk/slovnyk_ukrainskoi_movy _v_11_tomakh

${ }_{4}$ Великий тлумачний словник сучасної української мови / уклад. і голов. ред. В. Т. Бусел. Київ: 2009. С. 1365

5 Выготский Л.С. Мысль и слово. Общая психолингвистика: хрестоматия. Москва, 2004. С. 50-51. 
загальний світогляд людини, сприяє виробленню єдиної стратегії взаємодії, сприйняття та розуміння іншої людини.

Зміст спілкування реалізується за допомогою мови - системи умовних символів, якими передається поєднання звуків, що мають для людей певне значення і смисл. «Людське, мовне спілкування, як слушно зауважує Н. Кулібіна, в усіх своїх проявах $є$ єдністю комунікативного і когнітивного начал: ми говоримо і пишемо, щоб нас зрозуміли, а слухаємо і читаємо, щоб зрозуміти іншого» ${ }^{6}$.

Мовлення виникає через потребу в спілкуванні. Воно завжди спрямоване на слухача й призначене для спілкування 3 ним. Це однаково стосується як ситуативного мовлення, так i контекстуального. Але для того щоб бути адекватним засобом спілкування, мовлення в різних умовах повинно задовольняти різні вимоги і користуватися різними засобами.

Про це говорив відомий лінгвіст О. О. Леонтьєв, що реальний процес, який відбувається у спілкуванні, - це «встановлення відповідності між конкретною ситуацією і діяльністю, що підлягає позначенню, тобто між змістом, мотивом і формою цієї діяльності, 3 одного боку, та між структурою й елементами мовленнєвого висловлювання, 3 іншого». Під спілкуванням учений розуміє таку активність співрозмовників, у ході якої вони, впливаючи один на одного за допомогою знаків (у тому числі й мовних), організовують свою спільну діяльність ${ }^{8}$, тобто спілкування - це мотивований живий процес взаємодії між учасниками комунікації, спрямований на реалізацію конкретних життєвих настанов, що відбувається на основі зворотного зв'язку в конкретних видах мовленнєвої діяльності.

Мовленнєву діяльність психологи (Л. Виготський, О. О. Леонтьєв, I. Зимня, А. Лурія) розглядають як діяльність спілкування, а для успішного спілкування людина має «правильно й швидко орієнтуватися в умовах міжособистісної взаємодії, правильно спланувати своє мовлення, вибрати зміст, знайти адекватні мовні засоби для передачі думки і забезпечити зворотній зв'язок»".

У психологічній літературі мовленнєва діяльність розглядається як система мовленнєвих дій, які забезпечують спілкування - взаємодію двох або кількох мовців з метою обміну інформацією, що реалізується під час слухання, говоріння, читання і письма. Усі види мовленнєвої

${ }^{6}$ Кулибина Н.В. Художественный текст в лингводидактическом осмыслении. Москва, 2000. С. 274.

${ }_{7}$ Леонтьев А.А. Язык, речь, речевая деятельность. Москва, 1969. С. 147.

${ }^{8}$ Там само, С. 175.

9 Леонтьев А.А. Психолингвистические единицы и порождение речевого высказывания. Москва, 1969. С. 33. 
діяльності становлять основу спілкування як психологічної діяльності, а розвиток їх необхідний для формування умінь відтворювати й створювати (продукувати).

Поняття «спілкування» тісно пов'язане 3 терміном «комунікація». Зміст поняття «комунікація» трактується по-різному:

1) комунікація, за словниковими визначеннями, - це спілкування, що характеризується переданням інформації від однієї людини до іншої ${ }^{10}$; як лінгвістичний термін - те саме, що спілкування, зв'язок ${ }^{11}$;

2) спілкування, обмін думками, фактами, ідеями; специфічна форма взаємодії людей у процесі їхньої пізнавально-трудової діяльності; людська форма комунікації, характеризується, головним чином, функціонуванням мови ${ }^{12}$;

3) поняття, яке використовується: для характеристики структури ділових i міжособистісних відносин, для характеристики обміну інформацією в людському суспільстві взагалі. В останньому випадку комунікація виступає як один 3 аспектів людського спілкування інформаційний ${ }^{13}$.

Отже, комунікація - це процес обміну інформацією (фактами, ідеями, поглядами, емоціями тощо) між двома або більше особами, спілкування за допомогою вербальних і невербальних засобів із метою передавання та одержання інформації. Як бачимо, у наведених визначеннях комунікація пояснюється через спілкування і трактується як ширша наукова категорія.

Погоджуємося 3 Ю. Косенко, яка стверджує, що як терміни «комунікація» і «спілкування» можуть об'єднуватися тим, що означають в широкому значенні спілкування між людьми. «Слово «комунікація», - пише автор, - прийшло до нас через англійську мову (communication) від лат. communicatio - єдність, передача, з'єднання, повідомлення, пов'язаного з дієсловом (лат.) соттипісо - роблю спільним, повідомляю, з'єдную, похідним від (лат.) communis - спільний. Спільною ознакою цих понять є ідея єдності, проте є певна обмеженість слова «спілкування» щодо функціонування його в науковій сфері, оскільки питання вивчення процесів спілкування

${ }^{10}$ Великий тлумачний словник сучасної української мови / уклад. і голов. ред. В. Т. Бусел. Київ: 2009. С. 988.

${ }^{11}$ Словник української мови: в 11 тт. / АН УРСР. Інститут мовознавства; за ред. I.К. Білодіда. Київ: Наукова думка, 1970-1980. Т.9. С. 254. URL: http://ukrlit.org/slovnyk/slovnyk_ukrainskoi_movy_v_11_tomakh

${ }_{12}$ Словник синонімів української мови: у 2 т. / авт.-уклад. Бурячок А.А. та ін. Київ, 2006. Т. 2. С. 254.

13 Словник-довідник з української лінгводидактики: навч. посіб. / за ред. М.I. Пентилюк. Київ, 2015. 320 с. 
(комунікації) в західній науці було порушено набагато раніше, ніж в українській, тому слово «спілкування» має переважно нетермінологічний характер вживання. Усе це спричинилося до тлумачення кальки англ. слова «комунікація» як терміна 3 багатозначною структурою й обмеженого вживання рідного «спілкування» на позначення, зокрема, процесів масової комунікації» ${ }^{14}$. Ураховуючи змістову близькість понять «спілкування» і «комунікація», в нашому дослідженні вживатимемо їх як синонімічні.

У працях відомих психологів, психолінгвістів (О. Леонтьєв, I. Зимня, М. Скаткін, А. Хуторськой тощо) комунікативна діяльність розглядається як діяльність спілкування і вказується, що повноцінне ефективне спілкування можливе, якщо людина мотивована до нього, володіє такими вміннями, як правильно і швидко орієнтуватися в умовах спілкування, вибрати відповідний зміст спілкування, знайти адекватні мовні засоби для передачі думки і забезпечити зворотній зв'язок.

Отже, підсумовуючи все вищезазначене, спробуємо окреслити розуміння ефективного спілкування чи комунікації таким чином: це мотивована свідома комунікативна взаємодія двох чи більшої кількості комунікантів, що характеризується вмінням доречно й швидко орієнтуватися в умовах спілкування, враховувати їх у відповідному змісті повідомлення, добирати адекватні мовні й немовні (невербальні) засоби для передачі думки з метою забезпечення зворотного зв'язку, а також вміння оцінювати своє мовлення з позиції відповідності задумів і вміти корегувати його задля досягнення повного взаєморозуміння.

3 таких позицій цілком правомірно стверджувати, що повноцінного ефективного спілкування треба вчитися. Зауважимо, що воно - це не формулювання окремих речень, а передача цілісного певного смислу, акумульованого в тексті, де якість спілкування буде залежати від уміння володіти прийомами мовленнєвої діяльності.

А отже, особливої значущості в суспільстві в наш час та навчанні учнів у сучасній школі набуває комунікативна компетентність, що диктується вимогами життя й визначається як ключова компетентність учнів початкової школи, що й зазначається в Державному стандарті НУШ.

Наголосимо, що серед ключових компетентностей, які фіксують суспільно визначений комплекс певного рівня знань, умінь, навичок, ставлень, у Концепції НУШ головною є компетентність спілкування державною (i рідною у разі відмінності) мовами як уміння усно й

${ }^{14}$ Косенко Ю.В. Основи теорії мовної комунікації: навч. посіб. Суми, 2011. C. $17-18$. 
письмово висловлювати й тлумачити поняття, думки, почуття, факти та погляди (через слухання, говоріння, читання, письмо, застосування мультимедійних засобів); здатність реагувати мовними засобами на повний спектр соціальних і культурних явищ - у навчанні, на роботі, вдома, у вільний час; усвідомлення ролі ефективного спілкування ${ }^{15}$.

На користь цього твердження свідчать позиції учених Н. Бібік і О. Онопрієнко, які констатують, що в Національній рамці кваліфікацій (НРК) компетентність подано «як здатність випускника початкової школи самостійно використовувати в певному контексті різноманітні знання й уміння. До них віднесені: формування суджень, комунікативність, автономність і відповідальність, здатність до навчання й розвитку (уміння вчитися)» 16 . Комунікативність на цьому рівні розглядається як соціальна компетентність, що виявляється у здатності взаємодіяти у групах під час виконання спільних завдань, реалізовувати певну рольову поведінку, логічно висловлювати власні думки, вести діалог, здійснювати суспільно корисну діяльність ${ }^{17}$.

Не маючи на меті вдаватися до деталізованого аналізу поняття «комунікативна компетентність», усе ж вважаємо за доцільне подати розуміння даної дефініції в контексті проблеми нашого дослідження.

Наголосимо, що в останні роки науковці активно розглядають теорію комунікативної компетентності в контексті мовленнєвої поведінки. У відповідності до неї пропонують навчатися мов для встановлення співробітництва, міжкультурного діалогу, для координації дій, запобігання конфліктам. Відповідно, більшість дослідників розглядає здатність людей до ефективного спілкування усною чи письмовою рідною та іноземними мовами як суттєву ознаку комунікативної компетентності.

У розумінні комунікативної компетентності ми одностайні 3 Н. Соняк, яка трактує цю дефініцію як інтегровану здатність особистості, що виявляється передусім через набуття досвіду комунікативної діяльності, уміння усно й письмово висловлювати свої думки, почуття в різних комунікативних ситуаціях, зокрема в побуті, освітньому процесі, культурному житті, чітко й аргументовано пояснювати факти, а також через формування мотиваційно-ціннісної основи спілкування, відчуття краси слова, усвідомлення ролі мови для

15 Концепція Нової української школи / упорядники Гриневич Л., Калашнікова С., Коберник I. та ін.; заг. ред. Грищенко м. Київ, 2016. URL: https://mon.gov.ua/ua/ osvita/.../nova-ukrayinska-shkola

16 Формування предметних компетентностей в учнів початкової школи / Бібік Н.М., Вашуленко М.С., Мартиненко В.О. та ін. Київ, 2014. С. 90.

${ }^{17}$ Там само. С. 91. 
ефективного спілкування та культурного самовияву, готовність уживати українську мову як рідну в різних життєвих ситуаціях ${ }^{18}$.

Тож, комунікативна компетентність як умова ефективного спілкування - це мотивований живий процес взаємодії між учасниками комунікації, спрямований на реалізацію конкретних життєвих настанов, який відбувається на основі зворотного зв'язку. Ефективність спілкування досягається передачею цілісного певного смислу за наявності вмінь: орієнтації в умовах спілкування; усвідомлення комунікативних завдань; вміння правильно планувати висловлювання; доцільно вибирати зміст спілкування; знаходити адекватні засоби для передачі означеного змісту; забезпечувати зворотний зв'язок; оцінювати своє мовлення з позиції відповідності задумів й уміти корегувати його в наступній комунікації чи під час поточної.

Таким чином, комунікативна компетентність виступає базовою умовою ефективного спілкування й значною мірою залежить від визначення ii рівневої характеристики та основних компонентів (цілемотиваційного, комунікативно-когнітивного, комунікативнодіяльнісного) відповідно до визначеної структури комунікативної компетентності, яким буде приділено увагу в наступних параграфах.

\section{2. Дидактична гра як засіб формування комунікативної компетентності першокласників}

Реалізація сучасних Державних освітніх стандартів, головною рисою яких $\epsilon$ орієнтація освіти на результат - формування життєздатної, соціально активної, успішної особистості, що, зрозуміло, має реалізовуватися перш за все на основі системно-діяльнісного підходу, неможлива без нових педагогічних технологій. Оскільки діяльність - це перша умова розвитку в першокласника пізнавальних процесів: щоб дитина розвивалася, необхідно іiі залучити до різноманітних видів діяльності, в яких учень бачитиме результат, що далі мотивуватиме його до пізнання, отримання нових знань. Тож, освітнє завдання - на кожному етапі взаємодії з дитиною створити умови, які б спонукали дитину до дії, прищеплювали інтерес до знань, спираючись на цікавий і водночас змістовний матеріал. Такі умови, спираючись на психологічні особливості дітей, легко реалізувати в освітньому середовищі за допомогою дидактичних ігор, які на межі дошкільного й молодшого шкільного віку залишаються домінантним видом діяльності учнів цієї вікової категорії.

${ }^{18}$ Соняк Н.Л. Дидактичні умови формування комунікативної компетентності молодших школярів у процесі роботи 3 текстом : дис. ... канд. пед. наук. Луцьк Тернопіль, 2018. С. 29. 
Явище гри здавна привертало увагу вчених усіх галузей знань $\mathrm{i}$ дуже глибоко досліджено. Зарубіжні психологи (Г. Спенсер, К. Бюллер, $\Phi$. Шиллер, Ф. Бонтендайк) вивчали гру як фізіологічне й фізіопсихологічне явище; вітчизняні та зарубіжні психологи й педагоги (Н. Анікеєва, Л. Виготський, Г. Костюк, Н. Кудикіна, О.М. Леонтьєв, А. Макаренко, С. Рубінштейн, Д. Ельконін, С. Шмаков) переймалися питаннями теорії гри: досліджували іiі як соціально-педагогічний феномен (С. Шмаков), як природний засіб самовираження дитини (Н. Анікеєва), як вид діяльності поряд із навчанням i працею (Г. Селевко, С. Рубінштейн).

Дидактична гра відповідно до тлумачення українського педагогічного словника, - це різновид активної діяльності дітей, у процесі якої вони оволодівають суспільними функціями, стосунками, мовою як засобом спілкування між людьми. Це дитяче моделювання соціальних відносин. За умови правильного та вмілого керівництва 3 боку дорослих гра сприяє формуванню:

- емоційної, моральної й інтелектуальної сфер дитини;

- розвиває ії уяву;

- сприяє фізичному вдосконаленню;

- виховує волю до дії та здатність до гальмування - якості, необхідні людині в трудовій і суспільній діяльності ${ }^{19}$.

Дидактична гра вченими розглядається і як метод навчання, і як прийом, і як форма та засіб. Ми поділяємо точку зору тих учених, які розглядають гру як засіб навчання, і вважаємо за необхідне уточнити саме такий підхід у контексті нашого дослідження.

Насамперед необхідно відзначити, що дидактична гра $є$ засобом, який активізує пізнавальну діяльність, унаслідок чого учні мають можливість використати свої знання, уміння й навички в практичній діяльності ${ }^{20}$. Ї̈і сутність як засіб засвоєння знань виявляється в здатності успішно реалізовувати мету навчання, досягати реальних результатів, оволодівати досвідом творчої діяльності, моральних та інших якостей особистості. Ця здатність полягає в ігровому моделюванні конкретних видів діяльності (навчально-пізнавальної, науково-дослідницької, професійної тощо), спрямованих на відтворення i засвоєння соціального досвіду, внаслідок чого відбувається формування творчої, активної, соціально компетентної особистості.

3 точки зору діяльнісного підходу дидактична гра відрізняється від ігрової діяльності: це обов'язково сукупність двох взаємозалежних

${ }^{19}$ Гончаренко С.У. Український педагогічний словник. Київ: Либідь, 1997. С. 89.

${ }^{20}$ Крутій В.А. Активізація навчальної діяльності молодших школярів у процесі використання дидактичних ігор: дис. ... канд. пед. наук. Рівно, 2001. С. 180. 
видів діяльності - навчальної та ігрової, причому реалізація однієї 3 них - навчальної - здійснюється засобами іншої - ігрової. У процесі дидактичної гри окремі компоненти навчальної діяльності включаються в ігрову та утворюють у своїй єдності своєрідне ціле комбіновану форму: навчально-ігрову діяльність, що дозволяє використовувати іiі (гру) не лише в навчальному процесі, а коли діти розважаються.

Структурними складниками дидактичної гри є:

- дидактичне завдання, що визначається метою навчального й виховного впливу, формулюється педагогом i відтворює його навчальну діяльність;

- ігрове завдання, через яке в дидактичній грі реалізується дидактична задача, яка у грі зумисне прихована й постає у вигляді ігрового задуму;

- ігрові дії, які визначає ігрова задача. Ігрові дії - основа гри; різноманітність ігрових дій - запорука успіху у вирішенні ігрових завдань;

- правила гри, зміст і спрямованість яких зумовлені загальними завданнями формування особистості, пізнавальним змістом, ігровими завданнями й ігровими діями. Правила гри містять моральні вимоги до взаємовідношень між членами учнівського колективу, до виконання ними норм поведінки;

- результат гри. Підбиття підсумків проводиться відразу після закінчення гри. Це може бути підрахунок балів, визначення тих, хто краще виконав ігрове завдання, визначення команди-переможниці тощо $^{21}$.

Погоджуємося з В. Душиною, що у формуванні комунікативного досвіду чи то комунікативної компетентності дитини найкращих результатів можна досягти, граючись із нею. Досвід, який здобувається у грі, поступово застосовується і в інших формах життєдіяльності. Кожна гра виконує важливі виховні й комунікативні функції, формує типові навички соціальної поведінки й систему цінностей учнів. Саме в грі першокласник моделює способи спілкування, які спостерігає навколо, відображаючи у грі певні реальні події, стає їх безпосереднім учасником, ознайомлюється зі світом, діє активно, щиро сприймаючи все, що стосується гри ${ }^{22}$.

${ }^{21}$ Сергієнко Л.В. Дидактична гра як форма навчання в системі професійної освіти. Освіта на Луганщині. 2009. № 1. С. 152-154.

22 Душина В.А. Соціалізація дітей старшого дошкільного віку у просторі дитячої субкультури. Харків, 2012. 69 с. URL: http://lib.znaimo.com.ua/docs/166/index49114.html?page=4. 
Слушним доведенням ефективності дидактичної гри як засобу формування комунікативної компетентності дитини $є$ висновки дослідниці щодо соціального досвіду й умінь дитини, яких вона набуває в процесі ігрової діяльності. Це вміння: 1) контактувати (просто, доступно); 2) висловлювати свою думку (оцінювати); 3) виражати згоду (незгоду); 4) приймати пропозиції інших, не наполягаючи на своєму; 5) залагоджувати непорозуміння; 6) відповідати на поставлене запитання; 7) виявляти власну життєву позицію; 8) просити вибачення і пробачати інших; 9) запрошувати інших до гри; 10) брати активну участь у спільній грі; 11) гратися дружно в колективі; 12) мати оптимістичний настрій; 13) не конфліктувати тощо 23 .

Але ці вміння будуть сформовані вчителем за умови добору дидактичної гри передусім на основі глибокого знання педагогом i врахуванням в освітньому процесі психологічних особливостей першокласників.

Для визначення психологічних засад формування комунікативної компетентності учнів першого класу ми спиралися на концептуальні ідеї Л. Виготського та представників його психолінгвістичної школи (І. Гальперін, А. Залевська, І. Зимня, О. М. Леонтьєв, О. О. Леонтьєв, О. Лурія, О. Кубрякова тощо) щодо взаємозв'язку між навчанням та психічним розвитком дитини ${ }^{24}$.

Як відомо, діти молодшого шкільного віку допитливі, прагнуть пізнати світ, його численні факти і явища, отримати знання, опанувати різноманітні вміння, компетентності. Важливе місце при цьому належить мовленнєвій комунікації, що $є$ неодмінною умовою розвитку дитини, одним із найважливіших чинників ऑiі соціальнокомунікативного розвитку й формування комунікативної компетентності. Першокласнику, який перебуває на стадії перехідного періоду від гри до навчання, легше засвоювати матеріал, якщо інформація подається цікаво і яскраво. Такий пізнавальний інтерес $\epsilon$ базисом для засвоєння нових знань і формується різними способами (гра, елементи цікавості, проблемні ситуації тощо) як на різних етапах уроку, так і в позаурочній діяльності. Саме тому використання дидактичної гри може сприяти реалізації завдання НУШ створити таке гуманістичне навчально-предметне середовище, яке в сукупності забезпечить психологічний комфорт дитині, сприятиме розвитку iі здібностей,

${ }^{23}$ Душина В.А. Соціалізація дітей старшого дошкільного віку у просторі дитячої субкультури. Харків, 2012. 69 с. URL: http://lib.znaimo.com.ua/docs/166/index49114.html?page=4.

24 Выготский Л.С. Педагогическая психология. Москва : Педагогика-Пресс, 1996. $536 \mathrm{c.}$ 
формуватиме необхідні компетентності для ії соціалізації, розвиватиме творчість дітей молодшого шкільного віку на основі збереження цінностей дитинства.

У роботі не ставимо за мету досконало висвітлювати психологічні особливості дітей молодшого шкільного віку (6-10 років), а тому зупинимось на короткому узагальненні основних 3 огляду на порушену в роботі проблематику положень. У дитини молодшого шкільного віку, зокрема першокласника:

1. Спостерігається підвищений інтерес до всього нового, яскравого, цікавого й швидке його запам'ятовування. А $з$ огляду на «цифровізацію» сучасних школярів унаслідок перевантаження 3 раннього віку дитини усілякими гаджетами, новими інформаційними засобами та формування в дитини так званого кліпового сприйняття і мислення, стає очевидним, що привертатиме увагу одразу або зацікавлюватиме учня все нове, яскраве. Тому дидактична гра у своїй розмаїтості й виступає таким насиченим засобом для збудження пізнавального інтересу відповідно до особливостей сучасного першокласника.

2.Новоутвореннями першокласника $\epsilon$ зародження природних мотивів до навчання на тлі зміни основного виду діяльності - від ігрової в дошкільництві до навчальної в початковій школі та входження в нові колективні форми взаємодії. Тому в процесі відбору дидактичних ігор потрібно надавати перевагу тим, у змісті яких передбачено чітке визначення ролей учасників гри та зрозуміло й доступно обгрунтовано їхні правила.

3.У першокласників на основі їхньої розвиненої наочно-образної пам'яті починають формуватись базові навчальні навички та вміння, що $\epsilon$ початком нового етапу складного психічного та інтелектуального розвитку особистості. Мислительні операції першокласника грунтуються переважно на безпосередніх спостереженнях. Тому доцільно використовувати й різного виду наочність, організовуючи дидактичну гру (іграшки, картинки, ілюстрації тощо). Такий підхід дозволить викликати у молодших школярів зацікавленість до участі у навчально-ігровій діяльності, а отже, забезпечить краще запам'ятовування навчальної інформації, посилюючи природні мотиви до пізнання всього цікавого.

4. Мовлення дитини від діалогічного дошкільного ускладнюється до більш ємного смислового цілого, мотивованого, тобто розвивається зв'язне мовлення, вміння розкрити думку у зв'язній мовленнєвій побудові. В ігровій формі, де дитині пропонується від імені персонажа висловити думку не лише в діалозі з іншим персонажем, а й монологічно, ці важливі комунікативні навички формуватимуться природно.

5. Разом із тим дидактична гра $є$ ефективним засобом запобігання таким особливостям першокласника, як швидка втомлюваність, нестійкість уваги 
(переважно мимовільної), недостатньо диференційоване сприйняття внаслідок недосконалості аналітичного абстрагування. Часто змінюючи різні ролі та види діяльності в процесі виконання ігрових завдань, дитина не відчуватиме сильної втоми, іiі увага не розсіюватиметься й пізнавальна мотивація не послаблюватиметься, а формуватиме навички сприйняття реалій дійсності на основі виділення головного, суттєвого.

6. Підвищена чутливість, довірливе ставлення до авторитету вчителя, вразливість, висока реактивність у рухах, спрямованість на навколишній світ, наслідувальність у діях. Такі чинники, як радість пошуку, гордість відкриття, азарт змагання, бажання перемогти в грі, бути першим викликають та підтримують увагу дітей молодшого шкільного віку.

Переважною більшістю дослідників зазначається, що використання дидактичних ігор у навчальному процесі великою мірою сприяє появі в учнів інтересу до пізнання, оскільки дидактичні завдання, що ставить учитель перед учнями, сприймаються як гра (А. Артемова, В. Крутій, С. Роман, В. Яковлєв). Увага, пам'ять, мислення спрямовані на гру, а не на іiі навчальний компонент.

Дидактичні ігри є ефективним засобом для реалізації виховних цілей навчання. Організація їх на уроках допомагає розвивати у школярів самостійність, відповідальність, активність, а також дозволяє випробовувати власні можливості, аналізувати помилки та активізувати приховані здібності ${ }^{25}$. Гра, на відміну від традиційних засобів навчання, не лише передає певну суму знань, а насамперед розвиває здібності аналізувати, синтезувати, застосовувати одержану інформацію. Крім того, дидактичні ігри мають колективний характер і викликають потребу в спілкуванні (Н. Кудикіна) ${ }^{26}$, що й визначає їхню універсальність як засобу у формуванні навичок ефективного спілкування першокласників.

\section{3. Експериментальне доведення ефективності дидактичних ігор як засобу формування комунікативної компетентності першокласників}

Ефективне спілкування як неодмінна умова розвитку, один із важливих чинників соціально-комунікативного розвитку учня реалізується через комунікативну компетентність і залежить від рівнів іiї сформованості в першокласника.

${ }^{25}$ Крутій В.А. Активізація навчальної діяльності молодших школярів у процесі використання дидактичних ігор: дис. ... канд. пед. наук. Рівно, 2001. С. 180.

Кудикіна Н.В. Теоретичні засади використання інтелектуальних ігор у підручниках для молодших школярів. Проблеми сучасного підручника. Київ: Педагогічна думка. 2003. С. 239-243. 
Для доведення ефективності використання дидактичної гри як засобу формування комунікативної компетентності першокласника було проведене дослідження, спрямоване на вивчення реального стану сформованості навичок ефективного спілкування на початку навчального року та через півроку після активного застосування в освітньому процесі різних дидактичних ігор (рольових, режисерських, групових, з використанням ЛЕГО, танграм тощо).

Для цього було застосовано класичний педагогічний експеримент: вибрано перші класи в школах Луганської, Донецької областей i розподілено по 180 учнів (контрольний i експериментальний), визначено рівні, критерії та показники окресленого поняття на основі даного нами розуміння поняття ефективного спілкування молодшого школяра, яке ми трактуємо як мотивовану свідому комунікативну взаємодію на основі комунікативної компетентності двох чи більшої кількості дітей між собою чи 3 дорослим(ми), що характеризується вмінням дитини доречно й швидко орієнтуватися в умовах спілкування, враховувати їх у відповідному змісті повідомлення, добирати адекватні мовні й немовні (невербальні) засоби для передачі думки 3 метою забезпечення зворотного зв'язку, а також вміння оцінювати своє мовлення з позиції відповідності задумів і вміти корегувати його задля досягнення повного взаєморозуміння.

Спираючись на розуміння сутності основного поняття, з урахуванням компетентнісного й діяльнісного підходів у викладанні предметів мовнолітературної галузі (відповідно до Держстандарту НУШ), в ході яких і відбувається цілеспрямоване формування комунікативної компетентності першокласників, вибираємо такі критерії: иілемотиваиійний, комунікативно-когнітивний, комунікативно-діяльнісний, за якими й може бути визначена ефективність формування комунікативної компетентності молодших школярів.

Для оцінювання сформованості комунікативної компетентності першокласників було визначено рівні - високий, достатній, середній, початковий - відповідно до ступеня виявлення змістового вираження показників. Вимірювання здійснюється окремо за кожним показником методом спостережень, експертних оцінок та за вказаними методиками (табл.1), і кількісне вираження оцінки дуже умовне, оскільки навчальні досягнення учнів у 1-му класі підлягають формувальному оцінюванню. Представимо узагальнено інструментарій вимірювання в таблиці 1.

На початку було здійснено оцінку рівня сформованості комунікативної компетентності всіх першокласників, що дозволило констатувати загалом недостатній рівень комунікативної компетентності першокласників на початку навчання. Далі тими ж методиками було виміряно рівень комунікативної компетентності першокласників, які займалися півроку 3 щоденним використанням дидактичних ігор, і порівняно з результатами 
класів, де дидактичні ігри використовувалися не так часто. Отримані результати презентуємо в діаграмі 1.

Таблиця 1

Критерії, показники та діагностувальна база визначення сформованості комунікативної компетентності першокласників

\begin{tabular}{|c|c|c|c|}
\hline $\begin{array}{l}:= \\
0 \\
0 \\
0 \\
0 \\
0\end{array}$ & Показники & $\begin{array}{c}\text { Змістове вираження } \\
\text { показників } \\
\text { (Обов'язкові результати } \\
\text { навчання учня } \\
\text { 1-го класу) } \\
\end{array}$ & $\begin{array}{c}\text { Діагностувальні } \\
\text { методики }\end{array}$ \\
\hline 尝 & $\begin{array}{l}\text { - } \quad \text { прагнення до } \\
\text { спілкування, його } \\
\text { спрямованість; } \\
\text { - } \quad \text { позитивна настанова } \\
\text { щодо спілкування; } \\
\text { - } \quad \text { наявність } \\
\text { пізнавального інтересу; } \\
\text { - } \quad \text { спонуки до акт. самост. } \\
\text { вирішення навч. завдань }\end{array}$ & $\begin{array}{l}\text { - } \quad \text { сприймає усну інфор- } \\
\text { мацію, перепитує, виявля- } \\
\text { ючи увагу, доречно реагує; } \\
\text { - } \quad \text { розповідає про власні } \\
\text { відчуття та емоції від } \\
\text { прослуханого/ побаченого; } \\
\text { - } \quad \text { вибирає книжку для } \\
\text { читання; пояснює власний } \\
\text { вибір }\end{array}$ & $\begin{array}{l}\text { Анкета для першоклас. } \\
\text { на визначення рівня } \\
\text { потреби у спілкуванні; } \\
\text { анкета «Мотиви вибору } \\
\text { друга»; опитувальник } \\
\text { для вчителя щодо } \\
\text { оцінки рівня } \\
\text { сформованості } \\
\text { комунікат. компетент. } \\
\text { першокласників }\end{array}$ \\
\hline נִ: & $\begin{array}{l}\text { - } \quad \text { комунікативна } \\
\text { поінформованість; } \\
\text { - } \quad \text { компетентності } \\
\text { здійснювати мовленнєву } \\
\text { діяльність у процесі } \\
\text { спілкування; } \\
\text { - наявність певного рівня } \\
\text { комунікативних умінь: } \\
\text { сприймання, осмислення, } \\
\text { розуміння тексту чи } \\
\text { висловлення }\end{array}$ & $\begin{array}{l}-\quad \text { розпізнає ключ слова, } \\
\text { фрази в усному повідомл., } \\
\text { виділяє їх голосом у } \\
\text { власному мовленні; } \\
-\quad \text { висловлює думки щодо } \\
\text { усного повідомлення, прос- } \\
\text { того тексту, медіатексту; } \\
-\quad \text { намагається пояснити } \\
\text { свої вподобання; } \\
-\quad \text { намагається будувати } \\
\text { зрозуміле і цікаве } \\
\text { висловлювання; } \\
-\quad \text { правильно вимовляє } \\
\text { загальновжив. слова; } \\
\text { - } \quad \text { розпізнає образні } \\
\text { вислови і пояснює, що вони } \\
\text { допомагають уявити; } \\
-\quad \text { читає вголос правильно, } \\
\text { свідомо, нескладні за змістом } \\
\text { і формою тексти; } \\
-\quad \text { розуміє фактичний зміст } \\
\text { прочитаного } \\
-\quad \text { знає букви (друковані й } \\
\text { рукописні); }\end{array}$ & $\begin{array}{l}\text { тестові завдання } \\
\text { (на аудіювання та } \\
\text { репродукування задан. } \\
\text { тексту; на сприймання, } \\
\text { розуміння тексту); } \\
\text { дослідження словесно- } \\
\text { логічних здібностей } \\
\text { мислення } \\
\text { (Автор } \\
\text { Е. Замбацявичене, } \\
\text { модифікація } \\
\text { Л. Переслені та } \\
\text { О. Мастюкової) }\end{array}$ \\
\hline
\end{tabular}

27 Типова освітня програма під керівництвом Р.Б. Шияна. URL: https://nus.org.ua/news/opublikuvaly-typovi-osvitni-programy-dlya-1-2-klasiv-nushdokumenty/ 
Закінчення таблиці 1

\begin{tabular}{|c|c|c|c|}
\hline 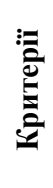 & Показники & $\begin{array}{c}\text { Змістове вираження } \\
\text { показників } \\
\text { (Обов'язкові результати } \\
\text { навчання учня } \\
\text { 1-го класу) }\end{array}$ & $\begin{array}{c}\text { Діагностувальні } \\
\text { методики }\end{array}$ \\
\hline 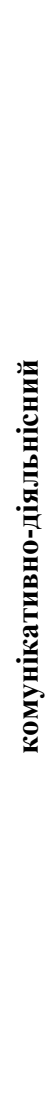 & $\begin{array}{l}\text { - } \quad \text { мовленнєва } \\
\text { діяльність (вербальна } \\
\text { й невербальна); } \\
-\quad \text { активна } \\
\text { комунікація; творче } \\
\text { продукування } \\
\text { повідомлень, власних } \\
\text { висловлень, текстів } \\
\text { різних типів, жанрів, } \\
\text { стилів залежно від } \\
\text { мети та } \\
\text { комунікативної } \\
\text { ситуації }\end{array}$ & $\begin{array}{l}-\quad \text { відтворює основний } \\
\text { зміст усного } \\
\text { повідомлення відповідно } \\
\text { до мети; } \\
\text { - } \quad \text { висловлює власні } \\
\text { погляди щодо предмета } \\
\text { обговорення; } \\
\text { - } \quad \text { розпізнає емоції своїх } \\
\text { співрозмовників; } \\
\text { - } \quad \text { використовує відомі } \\
\text { верб. та невербальні } \\
\text { засоби для передачі } \\
\text { емоцій та настрою; } \\
\text { - } \quad \text { розпізнає образні } \\
\text { вислови і пояснює їх, } \\
\text { намагається } \\
\text { використовувати у } \\
\text { власному мовленні; } \\
-\quad \text { ввічливо спілкується; } \\
-\quad \text { пов’язує інформацію з } \\
\text { тексту з життєвими } \\
\text { ситуаціями; розрізнює } \\
\text { головне і другорядне; } \\
\text { визначає тему худ. твору; } \\
-\quad \text { розповідає про } \\
\text { почуття та емоції від } \\
\text { прочитаного; } \\
-\quad \text { експериментує з } \\
\text { текстом (змінює кінцівку) } \\
\text { - пише рукописними } \\
\text { буквами, розбірливо. }\end{array}$ & \begin{tabular}{|l} 
дослідження рівня \\
розвитку зв’язного \\
мовлення молодшого \\
школяра (за описом \\
Л.Г. Терлецької); \\
критерії оцінювання \\
діалогічного та \\
монологічного \\
мовлення учнів
\end{tabular} \\
\hline
\end{tabular}

За результатами, представленими на діаграмі, видно, що навчальний процес з урахуванням компетентнісного підходу в освіті та нові методики викладання в НУШ, зокрема дидактична гра, суттєво підвищує рівень сформованості комунікативної компетентності першокласників. 


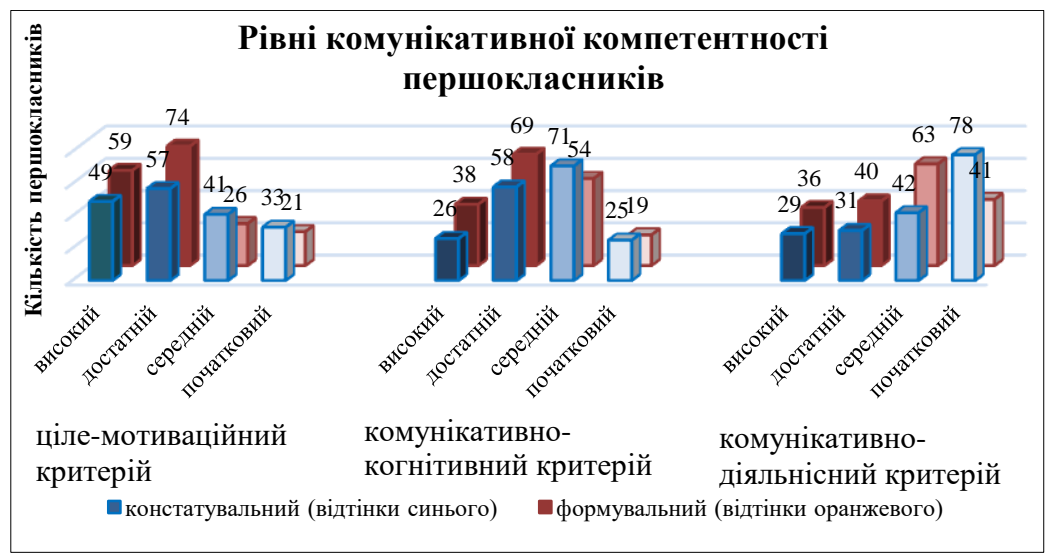

Рис. 1. Порівняльна діаграма рівнів комунікативної компетентності першокласників (констатувальний та формувальний етапи)

Так, як засвідчує діаграма, за ціле-мотиваційним критерієм за високим та достатнім рівнями зростання показників відбулося на 5,6\% 3 27,2\% до $32,8 \%$ і на 9,4\% з 31,7\% до 41,1\% відповідно, а за середнім і початковим спостерігається зменшення на 8,3\% з 22,7\% до 14,4\% і на 6,6\% 3 18,33\% до 11,7\% теж відповідно, адже рівень прагнення до спілкування, позитивна настанова, наявність пізнавального інтересу вже у 12 та 15 першокласників діагностувався не як початковий i середній рівень комунікативної компетентності, а середній і достатній відповідно. За наступними двома критеріями спостерігаємо теж позитивну динаміку, що цілком дозволяє засвідчити ефективність використання дидактичної гри у формуванні комунікативної компетентності як умови ефективного спілкування першокласника сучасної НУШ.

\section{ВИСНОВКИ}

Резюмуючи вищевикладене, констатуємо, що спілкування - це мотивований живий процес взаємодії між учасниками комунікації, спрямований на реалізацію конкретних життєвих настанов, який відбувається на основі зворотного зв'язку. Ефективне спілкування - це передача цілісного певного смислу, що базується на вміннях орієнтуватися в умовах спілкування; усвідомлювати комунікативні завдання; правильно планувати висловлювання; обирати зміст спілкування; знаходити адекватні засоби для передачі означеного змісту; забезпечувати зворотний зв'язок; оцінювати своє мовлення з позиції відповідності задумів.

Реалізація комунікативних стратегій у початковій освітній ланці досягається шляхом застосування комунікативного підходу до навчання, метою якого $\epsilon$ підготовка молодших школярів до 
повноцінного спілкування в усній і писемній формі, тобто формування у них комунікативної компетентності.

На основі психологічних особливостей першокласників, аналізу їхніх ключових новоутворень, які визначають особливості формування їхньої комунікативної компетентності уточнено поняття «ефективність спілкування молодшого школяра» - мотивована свідома комунікативна взаємодія на основі комунікативної компетентності двох чи більшої кількості дітей між собою чи 3 дорослим(ми), що характеризується вмінням дитини доречно й швидко орієнтуватися в умовах спілкування, ураховувати їх у відповідному змісті повідомлення, добирати адекватні мовні й немовні (невербальні) засоби для передачі думки 3 метою забезпечення зворотного зв'язку, а також вміння оцінювати своє мовлення 3 позиції відповідності задумів і вміти корегувати його задля досягнення повного взаєморозуміння.

Активний пошук демократичних результативних систем освіти, методів активізації освітнього процесу 3 позицій дитиноцентризму натепер, за Концепцією НУШ і за вимогами часу, робить дидактичну гру одним із дієвих засобів підвищення ефективності навчання, активізації пізнавальної діяльності учнів для формування комунікативної компетентності з урахуванням природи й психологопедагогічних особливостей першокласника. Дидактична гра в освітньому процесі стає засобом для створення гуманістичного навчально-предметного середовища на основі збереження цінностей дитинства, психологічно комфортного для молодшого школяра, яке сприяє розвитку його здібностей, формує необхідні компетентності для соціалізації особистості, розвиває творчість.

Для перевірки й доведення ефективності використання дидактичних ігор як засобу формування ефективного спілкування було проведено діагностуючі контрольні вимірювальні заходи за кожним визначеним критерієм.

Отже, використання дидактичних ігор забезпечує найкращі можливості для розвитку навичок ефективного спілкування й збереження дитинства, адже саме під час ігрової діяльності дитина здобуває ази соціально-комунікативної компетенції, оскільки за допомогою ролей осягає моделі міжособистісних відносин, накопичує знання і формує вміння користуватися мовою і правилами поведінки в соціумі, вчиться мистецтву спілкування.

\section{АНОТАЦІЯ}

У статті розглянуто проблему формування комунікативної компетентності як умови ефективного спілкування першокласників у контексті компетентнісного підходу до освітнього процесу з урахуванням положень Нової української школи. Проаналізовано поняття 
«спілкування», «комунікація», «комунікативна компетентність». На основі аналізу психолого-педагогічних та вікових особливостей учнів молодшого шкільного віку, зокрема першокласників, уточнено ключове поняття «ефективне спілкування молодшого школяра». На основі міждисциплінарного аналітичного дослідження презентовано гру як найбільш оптимальний засіб сприйняття й підтримання уваги, розвитку пам'яті й мислення сучасної «цифрової» дитини, який здатен цілком розв'язати питання гуманізації сучасного освітнього процесу 3 урахуванням потреб та інтересів школяра. 3'ясовано специфіку та теоретично обгрунтовано й практично доведено потенційні можливості дидактичної гри як оптимального психолого-педагогічного ефективного навчально-розвивального засобу формування комунікативної компетентності першокласників. Результати зрізу засвідчили позитивну динаміку, яка підтверджує ефективність дидактичної гри як засобу формування комунікативної компетентності першокласника.

\section{ЛIТЕРАТУРА}

1. Бібік Н. М., Вашуленко М. С., Мартиненко В. О. та ін. Формування предметних компетентностей в учнів початкової школи. Київ, 2014. 346 с.

2. Великий тлумачний словник сучасної української мови / уклад. i голов. ред. В. Т. Бусел. Київ: 2009. 1736 с.

3. Выготский Л. С. Мысль и слово. Общая психолингвистика: хрестоматия. Москва, 2004. С. 50-51.

4. Выготский Л.С. Педагогическая психология. Москва : Педагогика-Пресс, 1996. 536с.

5. Гончаренко С.У. Український педагогічний словник. Київ: Либідь, 1997. 376 с.

6. Душина В. А. Соціалізація дітей старшого дошкільного віку у просторі дитячої субкультури. Харків, 2012. 69 с. URL: http://lib.znaimo.com.ua/docs/166/index- 49114.html?page=4.

7. Концепція Нової української школи / упорядники Гриневич Л., Калашнікова С., Коберник І., Ковтунець В., Шиян Р. та ін. заг. ред. Грищенко М. Київ, 2016. URL: //https://mon.gov.ua/ua/ osvita/.../novaukrayinska-shkola

8. Косенко Ю. В. Основи теорії мовної комунікації: навч. посіб. Суми, 2011. $187 \mathrm{c.}$

9. Крутій В.А. Активізація навчальної діяльності молодших школярів у процесі використання дидактичних ігор: дис. ... канд. пед. наук. Рівно, 2001.311 с.

10. Кудикіна Н. В. Теоретичні засади використання інтелектуальних ігор у підручниках для молодших школярів. Проблеми сучасного підручника. Київ: Педагогічна думка. 2003. С. 239-243. 
11. Кулибина Н. В. Художественный текст в лингводидактическом осмыслении. Москва, 2000. 301 с.

12. Леонтьев А. А. Психолингвистические единицы и порождение речевого высказывания. Москва, 1969. 307 с.

13. Леонтьев А. А. Язык, речь, речевая деятельность. Москва, 1969. $214 \mathrm{c}$.

14. Рубинштейн С.Л. Проблемы общей психологии / редкол. Е. В. Шорохова. Москва: Педагогика, 1979.416 с.

15. Сергієнко Л. В. Дидактична гра як форма навчання в системі професійної освіти. Освіта на Луганщині. 2009. № 1. С. 152 - 154.

16. Словник синонімів української мови: у 2 т. / авт.-уклад. Бурячок А. А., Гнатюк Г. М., Головащук С. І., Горюшина Г. М., Лозова Н. Є., Мельник Н. Ю., Нечитайло О. І., Родніна Л. О., Тараненко О. О., Фридрак В. Б. Київ, 2006. Т.2. 960 с.

17. Словник української мови: в 11 тт. / АН УРСР. Ін-т мовознавва; за ред. І. К. Білодіда. Київ: Наукова думка, 1970-1980. T. 9. URL: http://ukrlit.org/slovnyk/slovnyk_ukrainskoi_movy_v_11_tomakh

18. Словник-довідник з української лінгводидактики: навч. посіб. / за ред. М. І. Пентилюк. Київ, 2015. 320 с.

19. Соняк Н. Л. Дидактичні умови формування комунікативної компетентності молодших школярів у процесі роботи з текстом : дис. ... канд. пед. наук. Луцьк - Тернопіль, 2018. 254 с.

20. Типова освітня програма під керівництвом P. Б. Шияна. URL: https://nus.org.ua/news/opublikuvaly-typovi-osvitni-programy-dlya-1-2klasiv-nush-dokumenty/

\section{Information about the authors:} Aleksieieva O. R.,

$\mathrm{PhD}$ in Pedagogic Sciences,

Associate Professor at the Pedagogical Department of Educational and Research Institute of Pedagogy and Psychology State Institution "Luhansk Taras Shevchenko National University" 1, Gogol Square, Starobilsk, Luhansk Region, Ukraine

Kurlishchuk I. I., $\mathrm{PhD}$ in Pedagogic Sciences, Associate Professor, Associate Professor at the Pedagogical Department of Educational and Research Institute of Pedagogy and Psychology State Institution "Luhansk Taras Shevchenko National University" 1, Gogol Square, Starobilsk, Luhansk Region, Ukraine 